\title{
KANDUNGAN BUAH-BUAHAN DALAM ALQUR'AN: BUAH TIN (Ficus carica L), ZAITUN (Olea europea L), DELIMA (Punica granatum L), ANGGUR (Vitis vinivera L), DAN KURMA (Phoenix dactylifera L) UNTUK KESEHATAN
}

Nur Khasanah ${ }^{1}$

\section{Abstrak}

Aneka ragam buah-buahan segar diciptakan Sang Khalik untuk umat manusia. Di antara sekian banyak buah-buahan itu, salah satu yang disebutkan Allah SWT dalam Alquran. Adalah buah tin, zaitun, delima, anggur, dan kurma. Untuk itulah kita sebagai muslim perlu mengetahui zat-zat yang terkandung dalam buah tersebut, sehingga dapat memanfaatkan buah tersebut dengan sebaikbaiknya. Tidak ada sekecil apa pun Allah ciptaan jika tidak membawa kemanfaatan bagi manusia.

Kata Kunci: Kandungan buah, kesehatan

\section{A. Pendahuluan}

${ }^{1}$ Dosen Fakultas Tarbiyah IAIN Walisongo Semarang 
“Dan Dialah yang menurunkan air hujan dari langit, lalu Kami tumbuhkan dengan air itu segala macam tumbuh-tumbuhan, maka Kami keluarkan dari tumbuhan-tumbuhan itu tanaman yang menghijau. Kami keluarkan dari tanaman yang menghijau itu butir yang banyak; dan dari mayang kurma mengurai tangkai-tangkai yang menjulai, dan kebun-kebun anggur, dan Kami keluarkan pula zaitun dan delima yang serupa dan yang tidak serupa. Perhatikanlah buahnya di waktu pohonnya berbuah, dan (perhatikan pula) kematangannya. Sesungguhnya, pada yang demikian itu ada tanda-tanda (kekuasaan Allah) bagi orang-orang yang beriman." (al-An'aam [6]: 99). “Demi (buah) Tin dan (buah) Zaitun" (At Tiin:1). ${ }^{2}$

Bagian dari ayat Al-Qur'an di atas menyatakan bahwa buah-buahan seperti; tin, zaitun, delima, anggur, dan kurma merupakan buah yang bagus untuk dikonsumsi. Berbagai penelitian telah banyak dilakukan untuk mengetahui komposisi dan kandungan yang terdapat dalam buah tersebut. Buah-buahan yang disebutkan dalam Al-Qur'an selain bagus untuk dikonsumsi, juga memiliki manfaat bagi kesehatan tubuh sampai untuk pengobatan terhadap suatu penyakit.

Dalam Al Qur'an, Allah Subhanahu wa Ta'ala sering menyebutkan buah anggur. Buah anggur merupakan nikmat Allah yang dianugrahkan kepada hamba hambaNYA di dunia ini dan di akhirat kelak. Anggur termasuk buah buahan yang sangat bagus dan banyak manfaatnya. Anggur adalah salah satu dari tiga buah buahan yang disebut sebagai " raja buah buahan" di samping kurma dan tin.

Di dalam tubuh terdapat suatu mekanisme menakjubkan yang bekerja untuk mempertahankan kesehatan tubuh yang disebut sistem imun tubuh. Sistem ini bekerja untuk melawan mikroba (bakteri, virus, parasit, jamur) dan toksin atau racun yang menyerang tubuh. Sistem imun tubuh melawan banyak mikroorganisme dan toksin setiap hari. Pada umumnya, sistem imun bekerja dengan baik dalam mempertahankan kesehatan

\footnotetext{
${ }^{2}$ Kementrian Agama RI. 1999. Al-Qur'an dan Terjemahannya. CV Toha Putra Semarang.
}

Jurnal PHENOMENON, Volume 1 Nomor 1, Juli 2011 
tubuh, akan tetapi kadangkala jika ada gangguan dengan sistem imun inilah yang bisa menyebabkan tubuh menjadi sakit ataupun bahkan terserang infeksi oleh mikroba.

Meskipun tubuh mempunyai sistem imun yang baik, tetapi dengan berbagai macam makanan siap saji yang banyak mengandung pengawet, pewarna, penyedap, dan pemanis yang dikonsumsi dapat berdampak pada berbagai penyakit yang dapat ditimbulkan. Dengan mengkonsumsi buah-buahan yang banyak mengandung gizi dan zat anti oksidan akan menjadi solusi persoalan dalam menjaga kesehatan kita. ${ }^{3}$

Banyak penelitian yang sudah dilakukan dari berbagai tanaman yang dapat digunakan sebagai obat. Karena itu kita perlu mengetahui apa saja zat yang terkandungan pada buah tin, zaitun, delima, anggur, dan kurma untuk kesehatan

\section{B. Buah Tin (Ficus carica L)}

Tin adalah buah-buahan yang mengandung zat sejenis alkalin yang mampu menghilangkan keasaman pada tubuh. Zatzat aktif yang terdapat dalam buah tin adalah sejenis zat-zat pembersih yang bisa dipakai untuk mengobati luka luar dengan cara melumurinya.

Unsur yang terkandung dalam buah Tin adalah karbohidrat, protein, dan minyak. Buah Tin juga mengandung yodium, kalsium, fosfor, zat besi, magnesium, belerang (fosfat), chlorin, serta malic acid dan nicotinic acid. Hasil penelitian lebih lanjut menyebutkan bahwa buah Tin termasuk buah yang dapat merangsang pembentukan hemoglobin darah, cocok sebagai obat penyakit anemia. Di samping itu buah Tin juga mengandung kadar glukosa yang cukup tinggi.

Menurut hasil penelitian medis, buah yang besarnya seperti buah kelengkeng itu selain kaya akan kalsium dan potasium juga mengandung zat benzaldehyde yang bermanfaat melawan sel-sel kanker. Di dalam buah tin yang rasanya manis itu juga mengandung zat yang sangat penting bagi tubuh manusia karepany New York.

${ }^{3}$ Kuby. J. 1997 Immunology $3^{\text {rd }}$ edition. W.H. Freeman and Com- 
na dapat mengurangi kolesterol jahat, menguatkan jantung dan menormalkan pernafasan bagi penderita sesak nafas. Buah yang juga dikenal dengan nama Ara atau Figs itu banyak dijumpai di negara-negara Arab. Buah ini mudah dicerna oleh alat pencernaan, bermanfaat untuk mengobati sulit buang air besar, bermanfaat untuk hati dan limpa.

Buah yang rasanya manis seperti korma ini juga lebih mirip sebagai makanan biasa karena mengenyangkan seperti buah korma sehingga warga Arab jarang memasukkannya dalam daftar buah-buahan.

Penelitian tentang kandungan benzaldehyde dalam buah Tin sebenarnya telah diungkap dalam jurnal yang dimuat website Cancer Cure Foundation. Website ini menyebutkan bahwa riset yang dilakukan para ahli dari Institute of Physical and Chemical Research di Tokyo menunjukkan benzaldehyde terbukti efektif dalam menghambat tumor.

Selain itu, Departemen Pertanian Amerika Serikat mengungkapkan bahwa buah Tin mengandung beragam nutrisi mulai dari vitamin A, C, kalsium, magnesium hingga potasium. Buah ini juga baik untuk mengendalikan nafsu makan dan membantu usaha penurunan berat badan. Jus buah Tin pun merupakan minuman yang baik untuk membunuh bakteri merugikan dalam sebuah peneltian.

\section{Zaitun (Olea europea $L)$}

Dalam dunia ilmiah, buah zaitun memilliki nama ilmia Olea europaea yang masih tergolong dalam famili Oleaceae. Pohon Zaitun merupakan pohon yang berumur panjang untuk masa yang lebih dari seratus tahun bahkan ribuan tahun. Ia menghasilkan buah secara terus-menerus tanpa harus menguras tenaga manusia, sebagaimana ia akan selalu nampak indah bila dipandang.

Zaitun dalam berbagai penelitian diyakini memiliki banyak khasiat dan keistimewaan, dari batang, daun hingga buahnya. Kandungan yang ada di dalam buah zaitun bagitu kompleks antara lain terdapat kadar protein, gizi dan anti oxidan yang besar, sebagaimana ia memiliki kadar garam yang mengand-

Jurnal PHENOMENON, Volume 1 Nomor 1, Juli 2011 
ung kalsium, zat besi, dan fosfat. Ini merupakan zat-zat penting dan vital yang dibutuhkan oleh tubuh manusia. Di samping itu buah/daun/minyak/juice Zaitun,dapat digunakan sebagai anti infeksi organ dalam, seperti, ginjal ,empedu dan mengandung senyawa koloid yang dapat membunuh sel-sel kangker.

Kandungan senyawa yang terdapat dalam zaitun seperti fenol, tokoferol, sterol, pigan dan squalene memegang peranan penting dalam kesehatan dan penyembuhan beberapa penyakit. Senyawa fenol diyakini berfungsi sebagi antioksidan yang sangat kuat. Kesemua senyawa yang bermanfaat itu tadi terkandung di dalam eksrtak buah zaitun yang berupa minyak. ${ }^{4}$

\section{Daun Zaitun}

Daun zaitun sudah lama dimanfaatkan masyarakat kuno Yunani sebagai pembasuh luka. Daun zaitun juga dipakai sebagai obat kandung kemih dan riset menunjukkan daun zaitun memiliki kemampuan membantu penurunan kadar gula dalam darah sebagaimana juga bermanfaat menurunkan tekanan darah tinggi. Daun tersebut juga mengandung zat anti mikroba dan sangat efektif memerangi sejumlah jamur, virus, dan bakteri.

\section{Minyak Zaitun.}

Minyak zaitun, yang diperoleh dari estrak buahnya berfungsi melindungi sistem pencernaan. Jika dioleskan pada bagian luar, minyak zaitun bisa melembabkan kulit dan berfungsi sebagai penghantar bagi minyak-minyak penting lainnya. Jika dipakai sebagai minyak goreng atau suplemen makanan, minyak zaitun dapat menjaga jantung dan pembuluh arteri tetap lentur. Konsumsi minyak zaitun secara teratur terbukti menghindari penimbunan kolesterol di pembuluh arteri. Dalam Al Qur'an diterangkan bahwa minyak zaitun dipakai untuk melembutkan dan menjaga elastisitas kulit serta kerap dioleskan untuk mempercepat penyembuhan kulit yang luka atau iritasi.

${ }^{4}$ Ahmad Zaki. 2008. Buah-Buah Yang Disebut Dalam Al-Qur'an. http:/ / ahmadzaki.wordpress.com/2008/09/01/buah-buahan-yang-disebut-dalamal-quran 


\section{Khasiat Minyak Zaitun}

a). Minyak Zaitun Berkhasiat Seperti ASI

Dalam sebuah studi modern yang dipublikasikan di bulan Februari 1996 M di Universitas Barcelona, Spanyol, yang dilakukan terhadap empat puluh wanita yang menyusui, diambil sampel ASI dari mereka. Para peneliti menemukan bahwa kebanyakan lemak yang terkandung di dalam ASI termasuk jenis lemak yang berantai tunggal. Jenis lemak ini dikategorikan sebagai lemak terbaik yang seharusnya dikonsumsi oleh manusia, dan itulah jenis lemak yang terkenal terdapat dalam minyak zaitun.

b). Minyak Zaitun Sebagai laksatif ringan untuk memudahkan proses buang air besar dan menyingkirkan cacing di dalam tubuh.

c). Minyak Zaitun Mengurangi Kolesterol Berbahaya

Dalam tubuh kita dikenal dua macam kolesteror yaitu LDL (Low Density Lipoprotein) dan HDL (High Density Lipoprotein). LDL dikenal sebagai kolesterol jahat yang merupakan menyebab utama terjadinya arterosklerosis atau penyumbatan pembuluih darah yang biasanya berujung pada jantung koroner. Sedangkan HDL merupakan kolesterol yang baik karena besarnya peranan dalam meningkatkan daya kekebalan (imunitas) tubuh.

d).Omega 9 yang terkandung dalam minyak zaitun dipercaya mampu menurunkan jumlah LDL dan menaikkan kadar HDL dalam tubuh kita. oleh karena itu kemungkinan terjadinya penyumbatan pembuluh darah yang berakibat pada penyakit jantung dapat diminimalisir.

e). Minyak Zaitun Mencegah penyakit jantung

Mengurangi Resiko Terjadinya Penyumbatan (Trombosis) dan Penebalan (Arteriosklerosis)

f). Pembuluh Darah

Dalam sebuah kajian para peneliti menyatakan bahwa nu- 
trisi yang kaya kandungan minyak zaitun bisa mengurangi pengaruh negatif lemak dalam makanan terhadap terjadinya pembekuan darah, dan selanjutnya mengu-rangi terjadinya penebalan pembuluh nadi jantung.

\section{g). Minyak Zaitun Mencegah kangker Payudara}

Kebiasaan mengkomsumsi satu sendok makan zaitun setiap hari, memungkinkan untuk dapat mengurangi terkena kanker payudara hingga $45 \%$.

h).Minyak Zaitun untuk mencegah kangker.

Kebiasaan menggunakan minyak zaitun memberikan peluang cukup besar untuk dapat melindungi diri dari sejumlah serangan kanker; kangker usus besar,rahim,indung telur. Penggunaan minyak zaitun untuk memasak selain menyehatkan juga mengurangi risiko kerusakan sel tubuh yang menyebabkan kanker.

Para ilmuwan yang telah menguji manfaat minyak zaitun. Menurut mereka, minyak zaitun mencegah terjadinya kerusakan sel tubuh yang menjadi penyebab kanker. Dalam riset yang dilakukan terhadap 182 orang di Eropa, para ahli menemukan bukti bahwa minyak zaitun mengurangi kerusakan oksidasi pada material genetik sel, di mana proses ini disebut-sebut bisa membuat sel kanker berkembang.

\section{i). Minyak Zaitun Menurunkan Angka Kematian.}

Sebuah studi yang dipublikasikan dalam majalah Lanst yang terkenal pada 20 Desember 1999 M, menunjukkan bahwa negara paling miskin di Eropa, yaitu Albania, yang berpenduduk muslim, memiliki keistimewaan sedikitnya angka kematian di sana. Angka kematian di Albania di kalangan pria adalah 41 orang dari setiap 100.000 orang, separoh dari keadaan di Britania. Hal itu dipengaruhi oleh konsumsi minyak zaitun dalam makanan para penduduk Albania.

j). Minyak Zaitun untuk kecantikan kulit dan rambut

Zat yang dimiliki minyakzaitun, merupakan sebuah zat yang 
mampu menjaga air menguap. Sehingga, zat ini amat baik untuk digunakan sebagai pelembab kulit. Minyak Zaitunjuga kaya akan vitamin E. mengkonsumsi buah dan minyak zaitun bisa memberikan kulit sehat, sama ketika dikenakan sebagai olesan. Teteskan minyak zaitun ke dalam air mandi hangat untuk tambahan kesehatan. minyak zaitun juga mengandung setidaknya 4 zat antioksidan yang berbeda. Hal ini berarti membantu menetralisir radikal bebas yang menyebabkan penuaan pada kulit dan kanker kulit. Orang-orang Arab banyak mengkonsumsi buah zaitu dan sekaligus minyaknya ini. Biasanya kaum wanita Arab meminyaki rambut mereka dengan minyak zaitun sebelum tidur kemudian berkeramas keesokan harinya menjadikannya lebat, tidak mudah rontok dan panjang.

k). Minyak Zaitun mengurangi dengkuran

Meminum minyak zaitun sebelum tidur bisa memberikan lubrikasi pada otot tenggorokan, sehingga dipercaya bisa mengurangi dengkuran. Termasuk juga mengurangi rasa gatal di tenggorokan. ${ }^{5}$

\section{Delima (Punica granatum L)}

Buah Delima (rumman) dalam Al Quran disebutkan di beberapa tempat, yaitu dalam Surat Al An'am 99 dan 141, serta Ar Rahman 68. Bagian bagian Buah Delima, terutama kulit luarnya mengandung asam tanat (Tannic Acid) yaitu zat pembasmi dan pembersih bakteri. Sedangkan jika diperas (dibuat jus) selain mengandung Tannic Acid juga zat gula mentol dan unsur besi dalam jumlah yang cukup tinggi. Menurut Ilmu Kedokteran, buah delima mempunyai manfaat antara lain; mengobati diare, ambeien, pelega nafas, cacingan, radang gusi, radang lambung dan obat mata.

Di Indonesia, delima dikenal dengan beberapa sebutan, tergantung daerahnya, seperti delima (Melayu), glima (Aceh),

${ }^{5}$ Khafi Kurnia. Republika Newsroom. Selasa, 28 Juli 2009. Mukjizat Buah Dalam Al-Qur'an. 
glineu mekah (Gayo), dhalima (Madura), gangsalan (Jawa), dalima (Sunda), teliman (Sasak), lele kase dan rumu (Timor).

Ada tiga jenis delima yang tersebar di Indonesia, dikelompokkan berdasarkan warna buahnya, yaitu Delima putih, Delima merah, dan Delima hitam. Dari ketiga jenis itu, yang paling terkenal adalah delima merah.

Delima merah sering ditanam di pekarangan rumah sebagai tanaman hias, sekaligus untuk dimakan buahnya. Beberapa kultivarnya yang kerdil bahkan telah dikembangkan khusus sebagai tanaman hias. Delima merah memiliki rasa yang lebih manis dan segar, sedangkan delima putih rasanya lebih sepat dan kesat, serta kurang manis.

Rasa kesat pada delima putih disebabkan oleh kandungan flavonoid (golongan polifenol) yang tinggi. Salah satu peran flavonoid yang penting adalah sebagai antioksidan. Hal itulah yang menyebabkan delima putih sering dimanfaatkan sebagai obat. Belakangan ini jenis delima putih agak sulit ditemukan di pasaran. Berdasarkan penelitian, kulit buah delima putih mengandung zat samak sebanyak 25-28 persen dan lendir 30 persen. Delima hitam kini menjadi tanaman langka yang tidak dikenal secara luas. Padahal, menurut para ahli, delima hitam lebih baik khasiatnya dibandingkan dengan delima putih.

Delima merupakan tumbuhan asli Persia dan daerah Himalaya di India Selatan. Menurut cerita, Pharaoh Tuthmosis membawanya ke Mesir pada tahun 1500 Sebelum Masehi. Dari sini, delima menyebar ke Afrika, Asia, Eropa, dan Amerika. Konon, tanaman ini bisa sampai ke Indonesia karena dibawa para pedagang dari Persia pada tahun 1416. Selama berabad-abad buah delima - telah dipakai sebagai simbol kesuburan di banyak agama dan kebudayaan. Sisa-sisa kepercayaan ini antara lain bisa dilihat pada upacara nujuh bulan kehamilan pada masyarakat Jawa. Pada acara tersebut, buah delima sebagai lambang kesuburan selalu hadir sebagai salah satu bahan rujak.

Bagi masyarakat Cina, buah delima merupakan salah satu buah wajib dalam menyambut Tahun Baru Imlek. Mereka percaya bahwa bijinya yang banyak merupakan simbol rezeki yang 
Nur Khasanah

melimpah.

\section{Komposisi Gizi}

Umumnya orang mengenal delima karena bentuk buahnya yang menarik, sehingga sering disajikan di meja untuk dimakan segar, tanpa memperhatikan khasiatnya. Buah yang sudah matang mengandung vitamin dan mineral yang bermanfaat bagi tubuh. Komposisi gizi secara lebih rinci dapat dilihat pada tabel. $^{6}$

Tabel. Komposisi Gizi per 100 gram Buah Delima

\begin{tabular}{|l|l|}
\hline Komponen Gizi & Per $100 \mathrm{~g}$ buah \\
\hline Air & $80-97$ \\
\hline Energi (kkal) & 68 \\
\hline Protein (g) & 0,95 \\
\hline Lemak (g) & 0,3 \\
\hline Karbohidrat (g) & 17 \\
\hline Kalsium (mg) & 3 \\
\hline Serat (g) & 0,6 \\
\hline Besi (mg) & 0,3 \\
\hline Magnesium (mg) & 3 \\
\hline Fosfor (mg) & 8 \\
\hline Kalium (mg) & 259 \\
\hline Natrium (mg) & 3 \\
\hline Seng (m) & 0,12 \\
\hline Tembaga (mg) & 0,07 \\
\hline Selenium (mg) & 0,6 \\
\hline Vitamin C & 6,1 \\
\hline Thiamin & 0,03 \\
\hline Riboflavin (mg) & 0,03 \\
\hline
\end{tabular}

${ }^{6}$ Made Astawam, 2010. Warisan Al Qur'an: Buah Delima (POME) Kaya Manfaat, http:/ / farrasbiyan.wordpress.com/2010/05/01/warisan-alquran-buah-delima-pome-kaya-manfaat 


\begin{tabular}{|l|l|}
\hline Niasin $(\mathrm{mg})$ & 0,3 \\
\hline Asam pantotenat $(\mathrm{mg})$ & 0,596 \\
\hline Vitamin B6 (mg) & 0,105 \\
\hline Asam folat $(\mathrm{mkg})$ & 6 \\
\hline Fitosterol $(\mathrm{mg})$ & 17 \\
\hline
\end{tabular}

Kandungan lainnya adalah gula inversi 20 persen (5-10 persen di antaranya berupaglukosa), asam sitrat (0,5-3,5 persen), asam borat, dan asam malat. Kombinasi tersebut menyebabkan buah delima berasa manis-asam menyegarkan. Asam malat juga bermanfaat untuk memperlancar metabolisme karbohidrat.

Mineral yang paling dominan adalah kalium (259 mg/ 100 g). Selain untuk menjaga tekanan osmotik (mencegah hipertensi), kalium juga membantu mengaktivasi reaksi enzim, seperti piruvat kinase yang dapat menghasilkan asam piruvat dalam proses metabolisme karbohidrat.

Di lain pihak, kandungan mineral natriumnya sangat rendah, yaitu 3 mg/ 100 g. Hal ini menguntungkan karena natrium berpotensi merugikan, yaitu dapat menimbulkan hipertensi (kebalikan dari kalium).

Buah delima merupakan simbol tua dari kemakmuran dan kesuburan, yaitu dalam bentuk upacara rujakan pada selamatan tujuh bulan kehamilan, yang dilakukan oleh masyarakat Jawa dan suku-suku lainnya di Indonesia. Selain dalam bentuk rujak, buah delima juga dikonsumsi dalam keadaan segar, jus, konsentrat atau sirop.

Jus delima merupakan minuman yang sangat populer di Eropa Timur dan India. Jus delima mulai dipasarkan secara luas di Amerika pada tahun 2004. Jus delima dapat diolah menjadi sirop grenadin, yaitu jus delima yang dikentalkan dan diberi gula. Minuman tersebut sangat berguna sebagai penyegar dan penghalau dahaga.

Akhir-akhir ini produksi dan kualitas buah di Asia Tenggara cenderung semakin menurun. Penyebabnya, hampir setiap bagian dari pohon delima dapat digunakan untuk tujuan-tujuan pengobatan, sehingga konsentrasi ke arah kualitas buah menjadi 
berkurang. Saat ini komponen tanaman delima selalu muncul dalam berbagai materia medika masyarakat Timur, yaitu untuk tujuan pengobatan berbagai penyakit.

\section{Obat Segala Macam Penyakit}

Hampir semua bagian tanaman delima dapat dimanfaatkan untuk pengobatan. Bagian daging buah, kulit buah, kulit batang, dan akar delima dapat diramu sebagai obat untuk berbagai jenis penyakit. Kulit buah dan kulit batang delima mengandung 20-30 persen elligatannin (tannin), triterpenoid, dan 0,5-1 persen alkaloid yang terdiri dari pelletierine yang sangat toksik atau beracun, methylpelletierine, dan pseudopelletierine. Biji, daun, serta bunga delima juga telah dimanfaatkan sebagai obat oleh berbagai bangsa dan kebudayaan untuk berbagai keperluan.

Sejak berabad-abad yang lalu, tanaman delima telah dikenal sebagai obat manjur untuk mengobati berbagai gangguan pencernaan, seperti diare dan disentri. Hal itu disebabkan tingginya kandungan tannin yang berkhasiat sebagai astringen, yaitu menyusutkan selaput lendir usus sehingga pengeluaran cairan diare berkurang. Sementara alkaloid pelletierine pada akarnya sangat membantu mengeluarkan cacing pita dan cacing gelang dari usus.

Kulit kayu dengan kandungan alkaloid pelletierine, lebih berkhasiat terhadap cacing pita (faenia) daripada cacing gelang (Askaris). Adanya tannin dalam jumlah besar pada kulit kayu sering menyebabkan rasa mual dan muntah. Karena itu, sebelum minum rebusan ini, disarankan puasa terlebih dahulu sekitar 12 jam.

Sejak zaman dahulu, buah delima sudah dikenal sebagai obat cacing. Ahli obat bangsa Yunani, Dioscorides, yang hidup pada abad ke-1, memanfaatkannya untuk tujuan tersebut. Alkaloid yang terdapat pada berbagai bagian tanaman delima menyebabkan cacing melepaskan pegangannya dari dinding usus, sehingga terbawa bersama tinja ke luar tubuh.

Namun, khasiat buah delima tersebut kemudian terlupakan di Eropa selama 1.800 tahun. Baru pada abad ke-19 para ahli 
pengobatan Barat mulai menelitinya kembali. Hal itu bermula karena ada orang Inggris yang disembuhkan dari penyakit cacingan setelah diberi ramuan buah delima oleh seorang herbalis India.

Sifat kelat dari kulit batang, daun, buah mentah, dan kulit buah dimanfaatkan dalam bentuk godokan untuk mengobati diare dan disentri. Kekelatannya itu disebabkan oleh senyawa tannin yang banyak terdapat pada bagian tanaman tersebut.

Penelitian lain menunjukkan bahwa senyawa tannin yang terkandung dalam akar delima mampu menghalangi Entamoeba histolytica, penyebab disentri amuba. Senyawa yang diketahui ampuh melawan cacing pita tidak hanya tannin, tetapi juga dua senyawa alkaloida piperidina yang terdapat pada kulit batang delima, yaitu pelletierine dan pseudopelletierine. Karena pelletierine dan isopelletierine sangat toksik, terutama yang terdapat pada kulit kayu dan kulit akarnya, penggunaan ekstrak kulit kayu dan akar delima sebagai pengobatan harus mendapat pengawasan dan seorang herbalis berpengalaman.

Beberapa penelitian menunjukkan bahwa tannin yang terkandung pada tanaman delima tidak hanya aktif sebagai antibakteri, tetapi juga melawan virus, antara lain penyebab penyakit cacar. Penelitian terbaru melaporkan bahwa delima dapat digunakan sebagai obat antidiabetes melitus atau kencing manis.

Kehadiran tannin juga dilaporkan dapat mereduksi risiko penyakit jantung. Hal itu, disebabkan oleh kemampuan tannin untuk mereduksi oksidasi kolesterol LDL (kolesterol jahat). Buah delima juga dapat mereduksi penyakit tekanan darah tinggi dengan menghambat pengubahan angiotensin I menjadi angiotensin II (penyebab darah tinggi).

Menurut pengobatan herbal tradisional Cina, biji delima mempunyai khasiat antiradang dan obat mujarab untuk mengatasi rematik. Bunga delima dipakai untuk mengobati radang selaput lendir pada gusi. Dan bagi mereka yang bermasalah dengan kegemukan (obesitas), bagian tanaman ini bisa dijadikan alternatif untuk mengatasinya.

Begitu juga kulit akar yang berkhasiat astringen bisa digu- 
nakan untuk mengobati diare, demam berulang, keputihan, dan mengatasi masalah berkeringat banyak. Sakit tenggorokan juga bisa diobati dengan berkumur air rebusan kulit akar delima.

Manfaat delima sebagai obat tidak hanya didasarkan pada pengalaman para pengobat tradisional. Beberapa penelitian ilmiah telah membuktikan manfaat tanaman delima. Penelitian Dr. Navarro dari Instituto Mexicano del Seguro Social, Meksiko, membuktikan bahwa ekstrak metanol yang terdapat pada kulit delima merupakan senyawa yang ampuh melawan bakteri penyebab diare, yaitu: Staphylloccus aureus, Escherichia coli, Pseudomonas aeruginosa, Salmonella typhi, dan Candida albicans.

\section{Hambat Pertumbuhan Sel Kanker}

Berdasarkan penelitian di University of California, AS, buah delima mempunyai efek ekstrogenik, yaitu menangkal gangguan menopause dan mencegah kanker pada organ-organ reproduksi. Jus delima yang telah difermentasi dan minyak yang diambil dari biji delima, juga diketahui aktif sebagai antioksidan yang setara dengan teh hijau.

Dengan minum satu gelas jus delima setiap hari, kita akan mendapatkan asupan senyawa antioksidan polifenol sebanyak $100 \mathrm{mg}$. Senyawa ini dapat melumpuhkan sel kanker dan memulihkan dinding arteri dari proses pengerasan. Biji delima juga mengandung polifenol. Itulah sebabnya jika membuat jus delima, sebaiknya diblender bersama bijinya.

Ekstrak buah delima mera secara in vitro (uji di luar tubuh) terbukti memiliki aktivitas antioksidan yang kuat, sehingga dapat bersifat kemopreventif (mencegah) atau kemoterapis (mengobati) sel kanker prostat (Malik et al, 2005). beberapa penelitian lain menunjukkan bahwa ekstrak delima juga berkhasiat untuk mencegah kanker payudara dan kanker kolon.

Penelitian para dokter di University of California menunjukkan bahwa sari buah delima dapat digunakan untuk menghambat kenaikan kadar prostate specific agent (PSA). PSA merupakan indikator pertumbuhan kanker prostat. Penelitan tersbut melibatkan 50 pasien yang sudah menjalani operasi maupun 
yang memperoleh terapi radiasi.

Setengah dari pasien tersebut diminta minum sari buah delima setiap hari dan setengah lainnya tidak (kelompok kontrol). Kadar PSA pasien itu kemudian dimonitor setiap bulan. Kadar PSA mereka yang tidak minum sari buah delima akan meningkat menjadi dua kali lipat hanya dalam waktu 15 bulan. Ada pun kadar PSA kelompok peminum sari buah delima memerlukan waktu hingga 54 bulan untuk meningkat menjadi dua kali lipat.

Lamanya waktu yang dibutuhkan untuk meningkatkan kadar PSA menjadi dua kali lipat tersebut oleh periset dipandang menguntungkan. Mereka jadi bisa menunda perawatan dengan hormon maupun kemoterapi, yang berarti menjauhkan mereka dari segala efek buruk yang menyertai terapi tersebut, membuka peluang untuk hidup lebih lama, serta memperoleh terapi lain yang tidak berbahaya.

Buah delima juga kaya akan fitosterol. Fitosterol merupakan komponen fitokimia yang mempunyai fungsi berlawanan dengan kolesterol bila dikonsumsi oleh manusia. Pada tahun 1970-an, fitosterol diketahui berfungsi menurunkan kadar kolesterol di dalam darah dan mencegah penyakit jantung, sehingga sangat bermanfaat bagi kesehatan manusia.

Beberapa hasil penelitian membuktikan fitosterol dapat mencegah penyakit kanker lewat berbagai mekanisme, yaitu menghambat pemecahan sel, menstimulasi kematian sel tumor, dan memodifikasi beberapa hormon yang berpotensi untuk menumbuhkan sel tumor (Awad et al, 2000).

Berdasarkan hasil penelitian yang dipublikasikan oleh Anticancer Research, terdapat hubungan signifikan antara konsumsi fitosterol dan pengobatan penyakit kanker. Hewan yang mengonsumsi fitosterol mempunyai ukuran tumor 33 persen lebih kecil dan sel kanker 20 persen Iebih sedikit, dibandingkan dengan kelompok kontrolnya.

Selain itu, fitosterol juga dapat membentuk permeabilitas kulit yang baik. Fitosterol dapat menjaga kelembaban kulit dan meningkatkan metabolisme kulit, serta mencegah inflamasi pada kulit. Fitosterol juga dapat mencegah penuaan kulit dan crythe- 
ma, yang disebabkan oleh polarisasi sinar matahari. Fitosterol juga membantu meningkatkan pertumbuhan rambut. Fitosterol juga tahan terhadap oksidasi, sehingga dapat digolongkan antioksidan pangan.

Fitosterol merupakan komponen penting pada sintesis vitamin D3 (Huang, 2004). Beberapa hasil penelitian membuktikan bahwa konsumsi 2-3 gram fitosterol sehari dapat mencegah PJK (penyakit jantung koroner) hingga 25 persen. Fitosterol juga mempunyai manfaat bagi penderita diabetes. Konsumsi fitosterol dalam jumlah yang cukup diketahui dapat menjaga keseimbangan gula darah.

\section{E. Anggur (Vitis vinivera L)}

Tanaman anggur diduga berasal dari sekitar Laut Hitam dan Laut Kaspi, kemudian menyebar ke Amerika Utara, Amerika Selatan, dan Eropa, selanjutnya ke Asia termasuk Indonesia. Secara umum, buah ini merupakan tanaman yang merambat. Ketinggian tempat yang baik adalah tidak lebih dari 300 meter di atas permukaan laut. Di Indonesia, tanaman ini telah dibudidayakan secara luas di Probolinggo, Situbondo, Banyuwangi, Palu, Malang, Pasuruan, Panarukan, Buleleng, dan Kupang. Menurut Food and Agriculture Organization (FAO), 71 persen dari total produksi anggur dunia digunakan untuk pembuatan wine, 27 persen sebagai buah segar, dan 2 persen sebagai buah kering. Daging buahnya mempunyai rasa asam manis, dan kandungan airnya banyak. Jenis asam yang dominan adalah asam maleat dan asam sitrat. Penyebab rasa manis pada anggur adalah tingginya kadar glukosa dan fruktosa.

Buah anggur termasuk dalam famili Vitaceae dan genus Vitis. Bentuk buah anggur hampir bulat dengan kulit buahnya berwarna merah kehitaman, hijau, kuning keemasan, atau ungu dan dilapisi tepung. Daging buahnya mempunyai rasa asam manis, dan kandungan airnya banyak. Jenis asam yang dominan pada anggur adalah asam maleat dan asam sitrat. Penyebab rasa manis pada anggur adalah tingginya kadar glukosa dan fruktosa. 
Prof Ali Khomsan menambahkan, berbagai penelitian menunjukkan, biji anggur mengandung pycnogenol sebagai penguat kolagen untuk kelenturan pembuluh darah (anti aging) dan kulit anggur ternyata kaya flavonoid dengan daya antioksidan lebih tinggi dari vitamin $\mathrm{C}$. Tak hanya itu, buah anggur sendiri kaya kalium untuk mengontrol tekanan darah.

Manfaat anggur telah banyak diteliti sebelumnya. Pada tahun 1870, ahli kesehatan Dr John Harvey Kellog, memberikan resep anggur untuk berbagai penyakit. Untuk kesembuhan, dia hanya memberikan resep makan buah anggur dengan takaran tertentu. Menurut The George Mateljan Foundation, anggur juga memiliki nilai gizi yang sangat luar biasa. Tiap 100 gram anggur paling tidak 25 komponen gizi yang dibutuhkan oleh tubuh. Sebut saja kalsium, kalium, vitamin A, Vitamin C, dan thiamin.

Kandungan mineral dalam anggur yang memiliki manfaat kesehatan bagi tubuh antara lain mangan. Zat itu sangat diperlukan tubuh dalam sintesis energi sehingga dapat membantu menjaga kestabilan gula dalam darah. Mangan juga diperlukan tubuh untuk metabolisme lemak dan pembentukan jaringan ikat dan tulang.

Anggur disebut mengandung karotenoid dan likopen yang tinggi. Kedua zat kimia tersebut dikenal luas akan kemampuannya menghambat berbagai penyakit tubuh. Kandungan antioksidan dalam anggur tersebut sudah diyakini kalangan luas sebagai pelindung sel dari radikal bebas penyebab penyakit degeneratif, seperti penyakit jantung, kanker, dan beberapa penyakit akibat penuaan.

Anggur mempunyai banyak khasiat bagi kesehatan karena kandungan kimia yang berada di dalamnya, salah satu di antaranya flavonoid. Flavonoid merupakan senyawa fitokimia yang memberikan warna ungu pada buah anggur. Flavonoid dapat mencegah oksidasi LDL (kolesterol jahat) 20 kali lebih kuat daripada vitamin E, yang selama ini dikenal sebagai antioksidan alami.

Kandungan vitamin C, B6, K dan B1 dalam anggur juga tinggi dengan khasiat yang luar biasa bagi tubuh. Vitamin $\mathrm{C}$ 
buah anggur dapat meningkatkan imunitas dan penyembuhan luka. Kandungan B6 pada anggur juga sangat penting untuk otak agar dapat berfungsi normal. Kulit anggur juga memiliki kandungan resveratrol yang merupakan sumber penting dari flavonoids, termasuk katekin, quercetin, prosianidin, dan antosianin. Resveratrol ditemukan pada sebagian besar kulit buah anggur. Penelitian beberapa tahun terakhir menyimpulkan, resveratrol kemungkinan dapat membantu awet muda dan mencegah kanker.

Selain itu, anggur terbukti dapat membantu kaum perempuan dalam mencegah sakit akibat pengobatan kanker payudara. Para dokter di Institute of Cancer Research membuktikan bahwa antioksidan yang terkandung dalam anggur dapat melindungi tubuh dari radiasi fibrosis, yakni pengerasan jaringan di sekitar payudara akibat radioterapi yang rasanya sangat menyakitkan. Kondisi ini dialami oleh ribuan perempuan di seluruh dunia setiap tahunnya.

Melalui tes laboratorium, jus anggur terbukti mampu menghentikan produksi hormon estrogen dalam sel. Penelitian terakhir menggunakan tikus yang ditanami sel tumor menunjukkan bahwa tikus yang diberi 0,5 ml jus anggur selama lima minggu, ukuran tumornya hanya sepertiga dari tikus yang tidak diberi jus anggur.

Namun demikian, sudah menjadi rahasia umum buah anggur termasuk jenis buah yang mahal bagi sebagian masyarakat di Indonesia. Harga satu kilogram anggur bisa mencapai puluhan ribu rupiah. Sehingga tidak semua lapisan masyarakat bisa mencicipi anggur.

Anggur sangat kaya antioksidan dan antimikroba. Kandungan zat gizinya tergolong excellent dan mampu menangkal berbagai penyakit. Manfaat lain, buah ini dapat meningkatkan gairah seks dan melelapkan tidur. ${ }^{7}$

Tabel 2. Berikut Komponen Gizi anggur per 100 gram

${ }^{7}$ Khafi Kurnia. Republika Newsroom. Selasa, 28 Juli 2009. Mukjizat Buah Dalam Al-Qur'an. 
Kandungan Buah-buahan Dalam Alqur'an:.....

\begin{tabular}{|c|c|}
\hline Komponen Gizi & Per $100 \mathrm{~g}$ buah \\
\hline Energi (kkal) & 69 \\
\hline Protein $(\mathrm{g})$ & 0,72 \\
\hline Lemak total $(\mathrm{g})$ & 0,16 \\
\hline Karbohidrat (g) & 18,1 \\
\hline Serat total $(\mathrm{g})$ & 0,9 \\
\hline Gula total (g) & 15,48 \\
\hline Kalsium (mg) & 10 \\
\hline Besi (mg) & 0,36 \\
\hline Magnesium (mg) & 7 \\
\hline Fosfor (mg) & 20 \\
\hline Kalium (mg) & 191 \\
\hline Natrium (mg) & 2 \\
\hline Seng (mg) & 0,07 \\
\hline Tembaga (mg) & 0,13 \\
\hline Mangan (mg) & 0,07 \\
\hline Selenium (mg) & 0,1 \\
\hline Riboflavin (mg) & 0,07 \\
\hline Niacin (mg) & 0,19 \\
\hline Vitamin B6 (mg) & 0,09 \\
\hline Folate total (mkg) & 2 \\
\hline Vitamin A (mg) & 66 \\
\hline Vitamin E (mg) & 0,19 \\
\hline Vitamin K (mkg) & 14,6 \\
\hline Thiamin (mg) & 0,07 \\
\hline Vitamin C (mg) & 10,8 \\
\hline
\end{tabular}

\section{F. Kurma (Phoenix dactylifera L)}

Berdasarkan kajian kimia dan fisiologi Dr Ahmad Abdul Ra'ouf Hisyam dan Dr. Ali Ahmad Syahhat, data berikut diperoleh ${ }^{2}$. Memakan ruthab dan atau tamar ketika berbuka puasa akan menambahkan peratus kandungan glukosa dan sukrosa dalam badan. 
Penyakit anemia (kurang darah) akan berkurangan dan tubuh tidak pucat. Ketika perut kosong, saat itulah makanan yang mengandungi nutrien glukosa dan sukrosa akan mudah dicerna dan diserap secara cepat dan maksimum. Jadi, kandungan glukosa dan sukrosa dalam ruthab dan tamar yang banyak itu menjadikan proses mencerna dan menyerap di dalam badan sangat mudah.

Kurma berserat tinggi, mengandung kalisum, potassium, folat, vitamin A, B, B1, B2, B3 C dan E, bebas lemak dan bebas kolestrol yang membantu dalam mencegah penyakit kronik seperti jantung dan kencing manis. "Dari segi perubatan, amalan memakan kurma setiap hari boleh mengurangkan risiko seseorang itu diserang penyakit kronik seperti jantung dan kencing manis kerana mengandungi zat galian seperti potasium, kalsium dan zat besi yang boleh menyihatkan sel darah merah". Prof. Madya Aslah Zain.

\section{Manfaat Kurma}

\section{Sangat Baik untuk Membantu Proses Persalinan}

Penelitian yang terbaru menyatakan bahwa buah ruthab (kurma basah) mempunyai pengaruh mengontrol laju gerak rahim dan menambah masa systolenya (kontraksi jantung ketika darah dipompa ke pembuluh nadi). Bahkan Allah Subhanahu wa Ta'ala memerintahkan Maryam binti Imran untuk memakan buah kurma ketika akan melahirkan, dikarenakan buah kurma mengenyangkan juga membuat gerakan kontraksi rahim bertambah teratur, sehingga Maryam dengan mudah melahirkan anaknya. Al-Hafizh Ibnu Katsir rahimahullah membawakan perkataan 'Amr bin Maimun di dalam tafsirnya : “Tidak ada sesuatu yang lebih baik bagi perempuan nifas kecuali kurma kering dan kurma basah (Tafsir Ibni Katsir (V/168), Tahqiq : Hani AlHaj, cet. Al-Maktabah At-Tauqifiyah, Mesir).

Dokter Muhammad An-Nasimi dalam kitabnya, AthThibb An-Nabawy wal Ilmil Hadits (II/293-294) mengatakan, "Hikmah dari ayat yang mulia ini secara kedokteran adalah, perempuan hamil yang akan melahirkan itu sangat membutuh- 
kan minuman dan makanan yang kaya akan unsur gula, hal ini karena banyaknya kontraksi otot-otot rahim ketika akan mengeluarkan bayi, terlebih lagi apabila hal itu membutuhkan waktu yang lama. Kandungan gula dan vitamin B1 sangat membantu untuk mengontrol laju gerak rahim dan menambah masa sistolenya (kontraksi jantung ketika darah dippompa ke pembuluh nadi). Dan kedua unsur itu banyak terkandung dalam ruthab (kurma basah). Kandungan gula dalam ruthab sangat mudah untuk dicerna dengan cepat oleh tubuh"

Ruthab (kurma basah) mencegah terjadi pendarahan bagi perempuan-perempuan ketika melahirkan dan mempercepat proses pengembalian posisi rahim seperti sedia kala sebelum waktu hamil yang berikutnya. Hal ini karena dalam kurma segar terkandung hormon yang menyerupai hormon oxytocine yang dapat membantu proses kalahiran. Hormon oxytocine adalah hormon yang salah satu fungsinya membantu ketika wanita atau pun hewan betina melahirkan dan menyusui.

Sedangkan Tamr (kurma kering) berfungsi untuk menguatkan sel-sel usus dan dapat membantu melancarkan saluran kencing karena mengandung serabut-serabut yang bertugas mengontrol laju gerak usus dan menguatkan rahim terutama ketika melahirkan.

\section{Menetralisir Asam}

Buah kurma kaya dengan zat garam mineral yang menetralisasi asam, seperti Kalsium dan Potasium. Buah kurma adalah makanan terbaik untuk menetralisasi zat asam yang ada pada perut karena meninggalkan sisa yang mampu menetralisasi asam setelah dikunyah dan dicerna yang timbul akibat mengkonsumsi protein seperti ikan dan telur.

\section{Kandungan Glukosa Sangat Tinggi Sehingga Baik un-} tuk Makanan Pertama Buka Puasa

Kandungan protein didalam kurma sebesar 1.8 - 2.0 persen, serat sebanyak $2.0-4.0$ persen dan gula sebesar $50-70$ persen glukosa. Dengan kandung gula seperti itu, kurma mampu memberi tambahan tenaga bagi orang yang berbuka puasa hingga ia akan merasa segar dan bertenaga uuntuk beribadah tanpa 
rasa letih ataupun mengantuk. Biasany, bagi yang merasa letih dan mengantuk disaat melaksanakan shalat tarawih disebabkan karena makanan yang dikosumsi kebanyakan mengandung karbohidrat yang tidak menyediakan tenaga instant (tambahan). Oleh karena itu, untuk menghindari hal tersebut, buah kurma adalah jawabannya.

Penelitian yang dilakukan Badan Kesahatan Dunia (WHO), zat gula yang ada didalam kurma itu berbeda dengan gula pada buah-buahan lain seperti gula tebu atau gula pasir yang biasa mengandung sukrosa dimana zat itu langsung diserap kedalam tubuh. Hal ini membuat gula itu harus dipecahkab terlebih dahulu oleh enzim sebelum berubah menjadi glukosa. Sebaliknya, kurma tidak menbutuhkan proses demikian.

Kurma sangat dianjurkan sebagai hidangan untuk berbuka puasa. Ada hal yang sudah ditetapkan dalam bidang kedokteran bahwa gula dan air merupakan zat yang pertama kali dibutuhkan orang berpuasa setelah melalui masa menahan makan dan minum. Berkurangnya glukosa (zat gula) pada tubuh dapat mengakibatkan penyempitan dada dan gangguan pada tulangtulang. Dilain pihak, berkurangnya air dapat melemahkan dan mengurangi daya tahan tubuh. Hal ini berbeda dengan orang berpuasa yang langsung mengisi perutnya dengan makanan dan minuman ketika berbuka. Padahal ia membutuhkan tiga jam atau lebih agar pencernaannya dapat menyerap zat gula tersebut. Oleh karena itu, orang yang menyantap makanan dan minuman ketika berbuka puasa tetap dapat merasakan fenomena kelemahan dan gangguan-ganguan jasmani akibat kekurang zat gula dan air.

\section{Mengatasi Sembelit}

Serat pangan yang terkandung dalam kurma cukup besar, sekitar 2,2 gram per 100 gram. Serat bermanfaat menurunkan kadar kolesterol dalam darah dengan menghambat penyerapan lemak atau kolesterol di dalam usus besar, sehingga kolesterol dalam darah tidak meningkat.

Kehadiran serat ini baik untuk mengatasi sembelit. Dengan tekstur serat yang cukup halus, kurma aman untuk lambung 
yang sensitif atau penderita radang usus. Sebagaimana pangan nabati lainnya, kurma tidak mengandung kolesterol. Kurma mengandung lemak baik yang bermanfaat bagi kesehatan.

Menurut ahli gizi IPB, Dr Hardinsyah MS, Direktur Klinik Konsultasi Gizi dan Klub Diet IPB ini mengatakan bahwa kurma mengandung zat gizi yang nyaris lengkap dengan komposisi yang seimbang, meskipun dalam jumlah yang serba sedikit.

\section{Kandungan Nutrisi Kurma}

Kandungan nutrisi kurma tergantung dari varietas kurma dan kandungan airnya. Umumnya mengandung zat-zat berikut Gula (campuran glukosa, sukrosa, dan fruktosa), protein, lemak, serat, vitamin A, B1, B2, B3, potasium, kalsium, besi, klorin, tembaga, magnesium, sulfur, fosfor, dan beberapa enzim.

Menurut Ahmad Said Joban, setiap 100 gram kurma mengandung kalsium $52 \mathrm{mg}$, iron 1,2 mg, magnesium $50 \mathrm{mg}$, fosfor $60 \mathrm{mg}$, potasium $667 \mathrm{mg}$, sodium $13 \mathrm{mg}$, klorida $271 \mathrm{mg}$, sulfur $14,7 \mathrm{mg}$, manganese $4,9 \mathrm{mg}$, copper $2,4 \mathrm{mg}$, zinc $1,2 \mathrm{mg}$, dan cobalt 1,9 mg. Juga vitamin A 90 IU, thiamin B1 $93 \mathrm{mg}$, ripovlavine B2 $144 \mathrm{mg}$, biotin 4,4 mkg, asam folio 5,4 mkg, niacin 2,0 mg, asam askorbat 6,1 mg, glukosa 38,5 gr, fruktosa 35,5 gr, gula jenis lain 3,4 gr, protein 2,35 gr, lemak 0,43 gr, dan energi 323.

Kandungan gulanya sebagian besar merupakan gula monosakarida, sehingga mudah dicerna tubuh, antara lain glukosa dan fruktosa. Pada varietas kurma tertentu, juga terdapat gula sukrosa. Kandungan gula pada kurma sangat tinggi, sekitar 70 persen, yaitu 70-73 gram per 100 gram. $^{8}$

\section{G. Penutup}

Buah dan tanaman sudah tidak diragukan lagi memiliki manfaat bagi kehidupan manusia terutama bagi kesehatan. Banyak penelitian yang membuktikan manfaat buah bagi kesehatan namun ada pula yang langsung diberikan keterangannya me-

\footnotetext{
${ }^{8}$ Khafi Kurnia. Republika Newsroom. Selasa, 28 Juli 2009. Mukjizat Buah Dalam Al-Qur'an.
} 
lalui Al Qur'an dan hadits beberapa di antaranya adalah buah Tin (Ficus carica L), Zaitun (Olea europea L), Delima (Punica granatum L), Anggur (Vitis vinivera L), dan Kurma (Phoenix dactylifera L)

"Ini menunjukkan bahwa betapa banyak nikmat yang Allah berikan dan sediakan untuk umat-Nya, baik ketika masih di dunia maupun kelak nanti di kehidupan abadi, yaitu surga bagi orang-orang yang bertakwa," Hisham Tahlbah dalam karyanya bertajuk Al-I'jaz Al Ilmi fi Alquran wa al sunnah (Ensiklopedia Mukzijat Alquran dan Hadis) yang telah dialihbahasakan kedalam bahasa Indonesia.[] 


\section{DAFTAR PUSTAKA}

Ahmad Zaki. 2008. Buah-Buah Yang Disebut Dalam Al-Qur'an. http:/ /ahmadzaki.wordpress.com/2008/09/01/buahbuahan-yang-disebut-dalam-al-quran

Kementrian Agama RI. 1999. Al-Qur'an dan Terjemahannya. CV Toha Putra Semarang.

Khafi Kurnia. Republika Newsroom. Selasa, 28 Juli 2009. Mukjizat Buah Dalam Al-Qur'an.

Kuby. J. 1997 Immunology $3^{\text {rd }}$ edition. W.H. Freeman and Company New York.

Made Astawam, 2010. Warisan Al Qur'an: Buah Delima (POME) Kaya Manfaat, http://farrasbiyan.wordpress. com/2010/05/01/warisan-al-quran-buah-delima-pomekaya-manfaat 